\title{
PROSPECTS AND CHALLENGES FOR THE UKRAINIAN AGRICULTURAL MARKET UNDER THE ASSOCIATION AGREEMENT WITH THE EUROPEAN UNION
}

\author{
Olexandr Radzivilıㄴ, Tetiana Minka², Yurii Sereda ${ }^{3}$, Oksana Strelchenko ${ }^{4}$, ${ }^{*}$ Yuriy Pyvovar $^{5}$ \\ ${ }^{1}$ Assoc. Prof. PhD. National Aviation University, Kyiv, Ukraine.E-mail stishovit@gmail.com \\ ${ }^{2}$ Assoc.Prof.ScD. University of Customs and Finance.E-mail Mtp2705@i.ua \\ ${ }^{3}$ PhD. Kyiv National Economic University named after Vadym Hetman, Kyiv, Ukraine. E-mail \\ sereda52443573@i.ua \\ ${ }^{4}$ Assoc. Prof. PhD. National Academy of Internal Affairs, Kyiv, Ukraine. E-mail \\ Strelchenko1977@i.ua \\ ${ }^{5}$ Prof. PhD. National Aviation University, Kosmonavta Komarova str. 1, 03058 Kyiv, Ukraine. \\ Phone+380673334886.E-mail pyvovaryi@gmail.com
}

Received 0426 2019; Accepted 30062019

The Association Agreement between Ukraine and the EU, on the one hand, opens up good prospects for increasing the competitiveness of Ukrainian agricultural producers, on the other hand, it causes a lot of difficulties related to the general state of the Ukrainian society. The purpose of this work is to identification prospects and challenges (risks) for the Ukrainian agricultural market in the course in provisions implementation of the Association Agreement between Ukraine and the EU. Research methods: the historical-sociological, system-structural analysis, comparative-legal, formallogical and hermeneutical researching helped to study of international universal and regional treaties in order to understand the contents of international standards related to international trade and the processes of its liberalization and the specifics of their applying in the agricultural sector during the acting of the General Trade Tariffs- 47 and under the auspices of the World Trade Organization. Results of the research - revealed the fluctuations of eurointegration sentiments in Ukraine. It has been proved that the prospects of cooperation between Ukraine and the EU and ways of their implementation in Ukrainian agricultural market should be understood in the context of historical circumstances. The key to success of reforms in Ukraine is to exclude caste privileges and build a civil society, taking into account the experience of the Western legal tradition.

Keywords: International agricultural trade, Association Agreement, Ukrainian society, Acquis communautaire, Public society, Agriculture, Prospects and Challenges.

JEL Codes: K33, Q13.

\section{Introduction}

Despite a con on the public, Ukraine keeps reposing on its European choice striving for ensuring human and civil values, vitally forgotten by the Ukrainians in recent centuries of imperial, totalitarian and post-totalitarian realias, back into interpersonal relationships. Signing European Union-Ukraine Association Agreement in 2014 speaks volumes for this.

Copyright (C) 2019 The Authors. Published by Vytautas Magnus University, Lithuanian Institute of Agrarian Economics. This is an open-access article distributed under the terms of the Creative Commons Attribution-NonCommercial 4.0 (CC BY-NC 4.0) license, which permits unrestricted use, distribution, and reproduction in any medium, provided the original author and source are credited. The material cannot be used for commercial purposes. 
At the same time, European integration public sentiment in Ukraine is marked by lack of temper in terms of time and space, and also in terms of various social groups, which is predetermined by the entire range of inconsistencies stemming from the USSR epoch.

Supposedly, the hottest ones are related to the conflict of interests of "successors" of elite who control politics, organized crime, and other strata, oriented towards caste system privileges and unjust enrichment at the expense of common public resource, on the one hand, and, on the other, - of the major bulk of impoverished working population, which, upon any regime, inevitably includes Ukrainian rural people, and who, frequently, unaware of this for subjective reasons, objectively requires building civil society in Ukraine, with levelling opportunities for everyone to have a decent standard of living, bring up healthy and successful children, and, if necessary, to obtain a guaranteed defence of their lawful interests at judicial bodies. At the turn of the centuries, the urgency of these social contradictions is being greatly enhanced as a consequence of powerful release of "spontaneous component" of human nature, predetermined by the crisis of value and worldview fundamentals of the social fabric of the previous century and uncertainty of such fundamentals for the upcoming one. Uninhibited by "rational component", which in such periods tends to lose a widely accepted benchmark, the "spontaneous component" is released in the most various social phenomena: from extensive liberation and propensity for freedom to the acts of "social barbarism" embodied both in interpersonal and inter-state relations such as "illegal requisitioning", "mergers and acquisition", occupation of neighbouring states' territories, and other criminal acts.

The general problems of rural regions and agriculture in this context are, perhaps, the most topical ones, as for a long time in Ukraine, upon drastic changes in city population composition, the country folk have been predominantly a member of cultural heritage of the Ukrainian people, remaining, however, the most disadvantaged group. At the same time, Ukraine has been traditionally seen as a vital component of ensuring food security of mankind, exporting agricultural products since the dawn of time. Already in $\mathrm{V}$ century B.C.E., Herodotus characterizes the territory of contemporary Ukraine as a breadbasket of the civilized world: Borysphenites, Scythians, Alazones, and other peoples of this land practiced agriculture and sold their harvest to foreigners in the cities of Black Sea and Azov regions (Herodotus, 2009). Polish-Lithuanian Commonwealth, the Russian Empire, and the Soviet Union were importing bread from Ukraine (even the Russian Empireat Holodomor time of 1932-1933 the soviet power exported Ukrainian crops and stored significant stocks of crops as reserves) (Smolii, 2003). Nowadays, the agricultural produce constitutes $37 \%$ of exported goods, whereas the export share of other export items (mineral raw materials, metallurgy, manufactured articles, etc.) makes up 63\% (World ..., 2017). Certainly, this is not the correlation of export items, which would speak for a developed country, however, this is an opportunity to receive currency and to be included into the structure of international economic connections, upgrading, at the same time, more promising industries, and, in the first place, education, which level stipulates all other parameters of development of society as well. In this regard, one could gain greater insight into the decisive 
importance for any country to have successful motives and professional capacities of those who represent their interests in external relations, in particular, Ukraine in the European integration processes.

Purpose of the paper is to identification prospects and challenges (risks) for the Ukrainian agricultural market in the course in provisions implementation of the Association Agreement between Ukraine and the EU.

Research object is the regularities of international-legal regulation of the agrarian market, as well as the current socio-political state of Ukraine and the society's readiness for qualitative changes in the agrarian sector in conditions of the European integration. The subject of the study is the international treaties of the universal and regional levels, which establish international standards of international trade and the process of its liberalization, as well as their influence on the Ukrainian agrarian sector.

Research methods. The material basis of the article consists of international agreements, as well as official statistics of the executive authorities of Ukraine. In the paper historical-sociological and system-structural analysis have been used, which helped to reveal the fluctuations of eurointegration sentiments in Ukraine and establish their connection with the inertia of unsolved social contradictions inherited since the existence of the Union of Soviet Socialistic Republics, which are particularly visible in a modern Ukrainian village. Comparative-legal, formal-logical and hermeneutical methods have been used in the study of international universal and regional treaties in order to understand the contents of international standards related to international trade and the processes of its liberalization and the specifics of their applying in the agricultural sector during the acting of the General Trade Tariffs- 47 and under the auspices of the World Trade Organization. Statistical method has been used to study the data of the Ministry of Economic Development and Trade of Ukraine, which made it possible to assume a social status of rural communities, and others.

\section{Research results and discussions}

The history of signing European Union-Ukraine Association Agreement speaks well for that the contemporary Ukraine is still having the long-term inertia of contradictions which foundation had been laid yet in the times of the USSR, or, even upon the Russian Empire epoch, which as a whole predetermines the nature of all prospects, failures, and achievements of our society, inclusive of success of deliveries on the potential and commitments which are directly stipulated and arise from the provisions of the Association Agreement, three protocols, and forty four Annexes thereto (UkraineEuropean ..., 2014). As it is known, Ukraine was the first among CIS countries that concluded the Partnership and Cooperation Agreement with European Union (hereinafter - PCA) even on June 14, 1994 (Partnership ..., 1994). Upon six months prior to this, on November 30, 1993, Ukraine also applied for membership to GATT-47, with an opportunity to turn out to be one of the founding states of WTO. Over the period 1991-1994, Ukraine adopted necessary laws adapted to the requirements of GATT-47 and founding treaties of the European Union. However, already at the end of that 
period, there emerged problems in economy. Although they were not so openly antisocial, as happened to be in the neighboring RF, however, under the pressure of the common for post-soviet societies processes, the relations in that sector were less and less falling under the legal regulation and were more and more getting criminalized. Supposedly, this may serve an explanation of the long timed ratification of PCA by the EU Member States, after which it took effect, namely March 1, 1998. In the same year, the Ukraine-EU Committee commenced its activity. Thus, clearly defined European integration aspirations of Ukraine that marked the first years of independence were not, in fact implemented, and even started to be negated under the second President's rule.

Only after his successor had been elected, Ukraine made a decisive move towards EU-integration: on February 21, 2005, for the purpose of implementation of the European neighborhood policy on Ukraine, the EU-Ukraine Collaboration Council adopted EU-Ukraine Action Plan (Proposed ..., 2005), which became a specification of the parties' commitments enshrined in PCA.

In March 2007, negotiations on new EU-Ukraine agreement commenced. First, the validity period of PCA was expiring in 2008, and, in spite of that the mechanism for annual automatic renewal of this agreement had been envisaged, the drastic changes taking place in the European Union, Ukraine, and worldwide at the beginning of XXI required a new agreement to be signed.

In particular, in May 2008, Ukraine became 152nd member to WTO, which opened an opportunity to create free trade area with the European Union. During Paris EU-Ukraine summit on September 2, 2008, it was decided that a new agreement should be an association agreement in the meaning of Article 217 of TFEU (EU-Ukraine ..., 2008). On April 16, 2009, at the meeting of the EU-Ukraine Collaboration Council the "EU-Ukraine Association Agenda" was signed: a declarative document aimed at its further specification and juridification. The term "association" in the meaning of Article 217 of the Treaty on the Functioning of the European Union (Treaty ..., 2007) means for Ukraine a deepened political cooperation, participation in EU "policies" and programs, and what is the most important is transforming the main objective from "collaboration" to "integration".

Certainly, the agreement in the meaning of the article 217 of the Treaty on the Functioning of the European Union (hereinafter - TFEU) is not a cornerstone of that a EU partner will become a candidate for accession to EU, however, the European Parliament in its recommendation as of July 12, 2007 proposed to duly reflect such prospects for Ukraine in the association agreement with the European Union (European ..., 2007). On December 19, 2011, it declared about completion of the negotiations on Association Agreement, and on July 19, 2012, the process of initializing of the text was finally over (European ..., 2007). The European Union - Ukraine association Agreement was to be signed at Vilnius Eastern Partnership Summit held in 2013. However, the signing of the Agreement was undermined by the Ukrainian government that was, - and only a nationwide protest against such failure and the subsequent events accelerated the process of signing and ratification of the Association Agreement between Ukraine and the European Union in the European Parliament during the year 2014. 


\section{Management Theory and Studies for Rural Business and Infrastructure Development eISSN 2345-0355. 2019. Vol. 41. No. 2: 153-167}

Article DOI: https://doi.org/10.15544/mts.2019.14

Prior to ratification of the Agreement by each Member State, the provisional application regime was put in placer, under which only those provisions of the Agreement were effective which fall within exclusive competence of the Union's institutions, under Article 2 of TFEU, and under common competence, under Article 3 of TFEU, with relation to the matters where the Union's institutes may act independently (Treaty ..., 2007). The Agreement took effect on September 1, 2017, three months after it had been ratified by the last EU Member State (The Netherlands).

The agriculture is only given a short Chapter 17 of the Association Agreement "Agriculture and rural development" in Title V "(Economic and Sector Co-operation", where it is stipulated that the Parties shall cooperate to promote agricultural and rural development, in particular through gradual approximation of policies and legislation (art. 403) (Ukraine-European ..., 2014).

There was singled out quite a significant range of specific areas of cooperation between Ukraine and the Union: a) facilitating mutual understanding of agricultural and rural development policies; b) enhancing administrative capacities at central and local levels for the planning, evaluation and implementation of policies; c) promoting modern and sustainable agricultural production, respectful of the environment and of animal welfare, including extension of the use of organic production methods and the use of biotechnologies, inter alia through the implementation of best practices in those fields; d) sharing knowledge and best practices of rural development policies to promote economic well-being for rural communities; e) improving the competitiveness of the agricultural sector and the efficiency and transparency of the markets as well as conditions for investment; f) disseminating knowledge through training and information events; g) favoring innovation through research and promoting extension services to agricultural producers; $h$ ) enhancing harmonization of issues addressed within the framework of international organizations; i) exchanging best practices on support mechanisms for agricultural policies and rural areas; $j$ ) promoting the policy of quality of agricultural products in the areas of product standards, production requirements and quality schemes (art. 404) (Ukraine-European ..., 2014). In pursuing the above cooperation, the Parties shall support gradual approximation of Ukraine to the relevant EU law and regulatory standards, in particular those as listed in Annex XXXVIII to that Agreement, and a regular dialogue shall take place on the matters covered by Chapter 17 (art. 405-406) (Ukraine-European ..., 2014).

Meanwhile, as the entire Title $\mathrm{V}$ is, Chapter 17 is perceived as a memorandum of intent, the implementation of which depends on many factors, among which the key ones seem those that include, firstly, real interest of the Parties to the Agreement in such implementation; secondly, existence of the procedurally well-thought and institutionally ensured, "vibrant" and unanimously reasoned feedback between those who represent the interests of Ukraine in relationship with EU and those for whom actually the improvements documented in Chapter 17, i.e. Ukrainian rural citizens, are planned. In this respect, of special difficulty seems to be the problem of involvement of rural population, in particular, organization of rural communities: the major part of them is essentially distorted, mainly because of the outflow of young people from neural 
regions and, in general, of employable population, whereas the lands that have been unlawfully placed into the category other than agricultural one have been bought out or otherwise transferred into ownership of physical and legal persons having nothing in common with rural communities. On the other hand, the social stratifying in rural regions gives rise to such relationships upon which a community loses its primary possibilities to advocate its interests, whereas their own and other large landowners behave as new feudal lords possessing a pseudo-absolute power. The social setback in rural regions is reflected in foreign trade aspects of the agricultural sector functioning: more than a third of agricultural produce exportation in the years of independence remains shadow.

According to assessments of the Ministry of Economic Development and Trade of Ukraine, in 2015, the size of the shadow sector in agricultural produce exportation was $40 \%$ of the official GDP, whereas, according to IMF's estimates, $-44.8 \%$. Over the last years, according to the data of the Ministry of Economic Development and Trade of Ukraine only, the shadow exportation share was reduced to 33\% in JanuarySeptember 2017 (Neboha, 2018), but it remains to be high yet. At the session of the Committee of the American Chamber of Commerce in Ukraine there were identified new schemes of making crop market shadow. These are, first of all, offshore export schemes and "manual" VAT refunding. Almost two thirds of export operations in Ukraine are made through offshore accounts (Neboha, 2018).

The question as to which conditions for export of agricultural produce Ukraine may be relied on in the context of EU Association Agreement are tangibly actual and specific. In this regard, it is a key point that the conditions for trade in agricultural produce between EU states and Ukraine have not been singled out in the Agreement, falling within general conditions of trade liberation, defined in Title IV "Trade and Trade-related Matters" (Ukraine-European ..., 2014). This is the largest title in terms of the size that contains fifteen chapters covering the full range of issues related to trade in goods, services, and intellectual property rights. The Title regulates common and specific matters of trade in goods; trade safeguard measures; conditions and forms of services provisions and issues related thereto such as trans-border movement of physical persons and establishment of enterprises; conditions of copyright protection; requirements to public procurement; protection of fair competition, and various forms of alignment of positions of the Parties. In all other stated matters, Ukraine shall approximate its standards and legislation to the standards of the European Union, come over the objective obstacles related to these processes, maintain an active dialogue with the Union, rely on its assistance and use it as efficiently as possible.

The conditions for harmonization of the problem of geographical indications governed by provisions of Sub-section 3 of Chapter 9 "Intellectual property" may serve a case of "asymmetry" of the requirements to the Parties to the Agreement. Having mutually admitted the main body of the provisions on intellectual property protection, under Annex XXII-A, and having planned the procedures for harmonization of the contradictory provisions, documented in Annex XXII-B, the Parties also agreed, formally in a symmetric manner, on protection of rights for geographic indications for agricultural and food products, singled out in Annex XXII-C, as well as for wines, 


\section{Management Theory and Studies for Rural Business and Infrastructure Development \\ eISSN 2345-0355. 2019. Vol. 41. No. 2: 153-167}

Article DOI: https://doi.org/10.15544/mts.2019.14

aromatized wines and spirit drinks, defined in Annex XXII-D (art. 202) (Ukraine-European ..., 2014).

Having no opportunity to become familiar with annexes, as the official website of the Verkhovna Rada provides their titles only, one can develop a view of existence of asymmetrical conditions for protection of geographic indications concerning agricultural products and spirit drinks at least from the list of the products given in pp. 3 and 4 of Article 208, which production and sale in Ukraine now requires either a license to be obtained or stoppage of the production thereof. The Common requirement to such products is defined as follows: "may continue to be sold in the territory of the Party where the product originated until stocks run out." (par. 2, art. 208) (Ukraine-European ..., 2014). However, for spirit drinks, in particular, for Champagne, Cognac, Madeira, Jerez, etc. (overall, there are 12 indications), the transitional period of 10 years from the entry into force of this Agreement is set out, and for cheeses (Parmigiano Reggiano, Roquefort, Feta) - a transitional period of seven years, during which these geographical indications may be used in order to "designate and present" (pp. 3,4, art. 202) (Ukraine-European ..., 2014).

It is obvious that lacking of specifically dedicated conditions in the Agreement for trade in agricultural produce formally corresponds to the objective defined by the World Trade Organization (hereinafter - WTO) - to subordinate the sectors, that have been withdrawn from the liberation process during the validity period of the General Agreement on Tariffs and Trade of 1947 (hereinafter GATT-47), i.e. from January 1, 1948 to January 1, 1995, when WTO commenced its activity, to the common rules of international trade.

As a WTO's agent, GATT-47 became, in the latter half of the $20^{\text {th }}$ century, legal and institutional basis for liberation of trade in goods, which, however, did not include raw goods, agricultural produce, textiles, and clothes. The neoliberal worldwide economic order, which formation started at the end of the Second World War, embodied, like liberalism did, the free trade principles, but was different from it due to active participation of the states in creation of contractual norms of international law and in establishment of international inter-state organizations aimed at facilitating to implement those norms.

That order was to be ensured by means of three institutional "pillars": two of them, established by Bretton Woods Agreements of 1944, started its activity since 1947: International Monetary Fund, which ensured control over predictability of national currency rates, and International Bank for Reconstruction and Development, which ensured the global coordination of movements of private funds. As for the third "pillar", the World Trade Organization was supposed to become suchlike, however, its Charter had not been ratified, though two Titles of the Charter, dedicated to protection of fair competition, were adopted as The Havana Charter in 1948. Whereas, it was GATT-47 as of October 30, 1947 (effective since January 1, 1948) that became the basic international agreement to have defined the rules for international trade liberation.

Both for Ukraine and for EU Member States, which are members to WTO, the obligatory norms of "multilateral agreements" of Marrakech package, including the 
Marrakesh Agreement Establishing the World Trade Organization as of April 15, 1994 and agreement of three annexes thereto, shall apply. Even prior to adoption of Marrakesh Agreement, the issues of liberation of international trade in agricultural produce was included in the Ministerial Declaration in Punta del Este made during Uruguay Round of GATT-47. In 1994, the Ministerial Conference recognized that, for agricultural products, WTO shall promote shaping of a "fair" but not "free" international market, and it is necessary to develop a liberation approach towards this sector in a consistent manner, having regard to the nature of the national markets of agricultural products (Carreau, Juilliar, 2001). Pursuant to this approach, the Member States shall in the long run to adapt all the trade sectors to the common international trade rules, however, in parallel, the system of specific and sectoral regulation of certain groups of goods, first of all of agricultural ones and textiles, is being developed (Carreau, Juilliar, 2001). The specific character of such regulation presupposes liberalization of the conditions and procedures for the overall waiving of the states from protectionism measures, assuming that, through flexible negotiation mechanisms, various safeguards, exempts and prolongations, special conditions are more advantageous over the general ones.

The Agreement on Agriculture (hereinafter - AoA) with the annexes thereto (Agreement on Agriculture, 1994) is directly dedicated to the procedure for liberation of international trade in agricultural produce; also, of great importance for the trade in agricultural produce is the Agreement on the Application of Sanitary and Phytosanitary Measures (hereinafter - SPS) with the annexes thereto (Agreement on the Application ..., 1994). These agreements are closely related with other agreements of Annex 1a to Marrakesh Agreement dedicated specifically to trade in goods, including: GATT94 (a comprehensive act under the title having GATT-47 as an integral part thereof) and twelve special agreements. AoA constitutes a first stage of liberation of trade in agricultural produce which was supposed to be further continued after completion of the initial period of validity of Agreement, which was set out for six years (those negotiations commenced in 2001 in the framework of Doha Development Round). It defines three basic requirements to the Member States: 1) to replace non-tariff barriers with customs tariffs; 2) to ensure adherence to the discipline of concessions in the course of opening of the national markets for importation of agricultural produce; 3 ) to restrict state support of agriculture, mainly, in the issues of export subsidies, which must be cancelled to the full extent (World ..., 1994).

As for opening of the markets for importation of the agricultural produce, it is necessary to take a note of application of safeguard measures first of all. Among the agreements of Annex 1a to Marrakesh Agreement, there is an Agreement on protective measures, which focuses specifically on the procedure for implementation of safeguard measures in response to massive importation of any other goods. The specific conditions of application of safeguard measures in response of the massive agricultural produce importation, as defined in Article 5 of AoA, will prevail over the general conditions, in case of their conflict (World ..., 1994). The conditions of application of specific safeguard measures for agricultural produce differ from the general conditions of application of protective measures (p.8, art. 5) (World ..., 1994). In particular, they shall remain in effect until complete liberation of the trade in agricultural produce (pp. 


\section{Management Theory and Studies for Rural Business and Infrastructure Development eISSN 2345-0355. 2019. Vol. 41. No. 2: 153-167}

9 and 20, art. 5) (World ..., 1994). Transformation of the quantitative restrictions into tariff measures keep options open for access of certain minimum quantity of goods to the markets of the importing state to which the safeguard measures apply. In this respect, Patrick Juillard and Dominique Carreau make a point at that due to the possibility of the guaranteed minimal access to foreign markets of the agricultural sector, the level of legal protectability of international trade in agricultural produce turns out to be higher than that of the commodity goods (Carreau, Juilliar, 2001).

The subsidies were subdivided into various categories even under GATT-47, among which there distinguished the unlawful (the majority of export subsidies) and lawful ones. However, in the course of the validity of GATT-47, the states reserved the right to grant subsidies for exportation of the agricultural goods provided that they did not strive for taking over a market share exceeding the fair level (art. XVI) (World ..., 1994). Following the outcomes of Tokyo Round in 1979, the Ministerial Conference adopted Subsidies Code defining the general conditions of granting subsidies, which were subsequently specified in one of the special agreements to Annex 1a to Marrakesh package (Agreement on Subsidies ..., 1994). The Agreement on subsidies and compensation measures also distinguishes unlawful (art. 3) (Agreement on Subsidies ..., 1994) and lawful subsidies, from which, in its turn, one of them (yellow subsidies) are received in response to retortion of the importing state in the form of countervailing duties, whereas others (green subsidies for improvement of ecological cleanness of products) are not granted (art. 2) (Agreement on Subsidies ..., 1994).

The member states to WTO undertook commitments to block existing level of support for reducing it by $30 \%$ over 6 years from the time when Marrakesh Agreement took effect. For the developing countries, this period is extended to 10 years, with level of the state aid reduction set out as $24 \%$. As for producers of agricultural produce, AoA provides for special conditions for the process of reduction and waiving of the states from granting subsidies (Baltzer, Jensen Hans, Lind Kim, 2009). For unification of regulation of this process, it was defined Total Aggregate Measurement of Support", Total AMS (mesure globale du soutien totale, MGS), principles and methods of calculation of which are provided in p. 1 pf Article 6 of AoA and Annex 3 thereto.

The general commitment of the member states to WTO is to reduce this indicator by $20 \%$ for over six years from the time Marrakesh package takes effect. However, there are specific types of state aid distinguished in p. 2 of Article 6 of AoA and Annex 2 to AoA and defined as "annual and final levels of binding commitments". As p. 2 of Article 6 stipulates, the governments of the developing countries shall be exempted from the obligations to reduce domestic support if they: grant aid for encouraging of agriculture development and rural regions as an integral part of the program for development of their countries; involve investment subsidies granted for programs of development of agriculture in developing countries; grant subsidies for agricultural raw products which are usually granted to the producers with lower level of income and poor raw materials base in the developing member states (Agreement on Agriculture, 1994). The state aid includes export subsidies, differentiated separately therefrom, which granting is easier than providing domestic support and which are unlawful as 
compared to the majority of other goods, and subjected even to a stricter treatment in terms of agricultural produce (art. 9) (Agreement on Agriculture, 1994).

The principle of separation of specific conditions for regulating international trade in agricultural produce as a specific agreement (AoA) of Annex 1a also complies with the European Union approach to this issue, where specific conditions for regulation and agriculture support policy are given as s separate Title III "Agriculture and Fisheries", in Part III "Domestic Policy" of the Treaty on the Functioning of the European Union of 2007 (Lisbon version of Treaty of Rome of 1957). Pursuant to Article 38 of that Agreement, the Union shall implement a common agriculture and fisheries policy, the aims of which include, respectively: a) to increase agricultural productivity by promoting technical progress and by ensuring the rational development of agricultural production and the optimum utilization of the factors of production, in particular labour; thus to ensure a fair standard of living for the agricultural community, in particular by increasing the individual earnings of persons engaged in agriculture; (c) to stabilize markets; (d) to assure the availability of supplies; (e) to ensure that supplies reach consumers at reasonable prices (p. 1, art. 39) (Treaty ..., 2007). As it can be seen, the aid to the rural regions is deemed here as an integral part of common policy.

In working out the common agricultural policy, the Commission shall take into account: (a) the particular nature of agricultural activity; (b) the need to effect the appropriate adjustments by degrees; (c) the fact that in the Member States agriculture constitutes a sector closely linked with the economy as a whole (p. 2, art. 39) (Treaty ..., 2007). Specific measures that may be taken in the framework of general rules may refer to the state aid as such, in particular, to regulation of prices, aids for the production and marketing of the various products, making reserves and carryover arrangements; and common arrangements for stabilizing imports or exports (p. 2, art. 40) (Treaty ..., 2007). Besides, provision may be made within the framework of the common agricultural policy for measures such as an effective coordination of efforts in the spheres of vocational training, research and the dissemination of agricultural knowledge; this may include joint financing of projects or institutions, and joint measures to promote consumption of certain products" (art. 41) (Treaty ..., 2007).

In order to attain the objectives set out in Article 39, a common organization of agricultural markets shall be established, which should be flexible in terms of methods for implementation, taking into account integration of national markets into common market broken down various types of agricultural produce. This organization shall take one of the following forms, depending on the product concerned: (a) common rules on competition; (b) compulsory coordination of the various national market organizations; (c) a European market organization (p. 1, art. 40) (Treaty ..., 2007). The rules on competition (which do not allow for state aid) shall apply to agricultural products only to the extent determined in the legislative acts (upon proposal of the Commission) by the European Parliament and the Council. Also, the Council, on a proposal from the Commission, may authorize the granting of aid: for the protection of enterprises handicapped by structural or natural conditions; within the framework of economic development programs (art. 42) (Treaty ..., 2007). For regulation of certain issues of agricultural sector, there were preserved non-tariff methods as well, in particular, the 


\section{Management Theory and Studies for Rural Business and Infrastructure Development eISSN 2345-0355. 2019. Vol. 41. No. 2: 153-167}

Council, on a proposal from the Commission, shall adopt measures on fixing prices, levies, aid and quantitative limitations and on the fixing and allocation of fishing opportunities (p. 3, art. 43) (Treaty ..., 2007).

Although all the measures on granting aid to agricultural sector are defined in Title III of TFEU as domestic policy issues, nevertheless, they may, first of all, further manifest the effect of implied support of the produce to be exported, and, secondly, state support of agriculture and facilitating of distribution of its produce onto foreign markets are those policy standards, which the European states are in no haste to refuse from at WTO forums.

For Ukraine, such standards should also become a guideline, moreover, Ukraine, having been referred in terms of many indicators to developing countries, may take use of these measures in much wider and diverse perspective than the developed countries do. Instead, as it has been stated above, the division into structural sub-sections in Association Agreement by no means records particular character of trade in agricultural produce. The text of the Agreement as such clearly defines preferences for trade in agricultural produce only with regard to the European Union, where Chapter 2 (Trade remedies) of Title IV "Trade and Trade-related Matters" specifies that EU Party reserves its rights and obligations, provided for by Article 5 of Agreement on Agriculture (p.1, art. 40) (Ukraine-European ..., 2014). On the whole, the text of the Agreement contains only references to the preferences. If one accounts for finding specific preferences concerning exportation of agricultural produce of Ukraine in relevant annexes to the Agreement, a weird situation should be made notice of: it is impossible to find the texts of the annexes at the official website of the Verkhovna Rada, but only titles of those annexes (Ukraine-European ..., 2014).

Instead, the detailization of the situation in which it is envisaged a wide range of controlling acts of the Parties, as well as consultations and procedures for dispute settlements, etc. contained in the text of the Agreement claims attention. For instance, in the same Title IV "Trade and Trade-related Matters" Chapter 1 "National treatment and market access for goods" contains quite a lengthy section 5 "Administrative cooperation and coordination with other countries", which defines importance of administrative cooperation of the Parties for implementation and control of the preferential treatment granted under Chapter 1 and for combating irregularities and fraud in customs matters, and also envisages that where a Party, on the basis of objective documented information, experiences a failure by the other Party to provide administrative cooperation or suspects the existence of irregularities or fraud from the part of other Party in the matters defined in Chapter 1, the Party concerned may temporarily suspend the relevant preferential treatment of the product(s) concerned in accordance with this Article (p. 2, art. 37) (Ukraine-European ..., 2014).

It also defines the features of such failure which entails relevant penalties: a) a repeated failure to respect the obligations to verify the originating status of the product(s) concerned; b) a repeated refusal or undue delay in carrying out and/or communicating the results of subsequent verification of the proof of origin; c) a repeated refusal or undue delay in obtaining authorization to conduct administrative cooperation 
missions to verify the authenticity of documents or accuracy of information relevant to the granting of the preferential treatment in question.

It also provides explanation of the signs of irregularities: a rapid increase, without satisfactory explanation, in imports of goods exceeding the usual level of production and export capacity of the other Party. Where the Parties have entered into consultations and have failed to agree on an acceptable solution within three months, the Party concerned may temporarily suspend the relevant preferential treatment. Such temporary suspensions shall be limited to what is necessary to protect the financial interests of the Party concerned. Each temporary suspension shall not exceed six months. However, a temporary suspension may be renewed (p. 3, art. 37) (Ukraine-European ..., 2014).

Considering the present-day setback in Ukraine and the level of corruptness of the bodies, in the context of Article 37 of the Association Agreement, which, under that Chapter, subject to control or which will be involved in settlement of disputable situations, it seems quite probable that, under certain circumstances, Ukraine will lose a great number of advantages and funds, given that it is consumers and taxpayers who traditionally will have to compensate the losses.

There is no escaping the drawbacks of the text of the Association Agreement, which themselves give rise to uncertainty in that the Agreement on behalf of Ukraine was drawn up by highly qualified experts having genuine desire and required knowledge for standing up for the interests of Ukraine and of a national producer in each paragraph of each article of the Agreement. There are many cases in the Agreement where the wording itself gives rise to the question as to whether their meanings were understood by the authors (translators) of the text. Some agreements of Marrakech package, to which the Association Agreement provides references, are named in the way other than they are provided at the website of the Verkhovna Rada: for instance, Agreement on safeguard measures is defined in the text of the Association Agreement as Agreement on specific measures (art. 45bis) (Ukraine-European ..., 2014), Preshipment Inspection Agreement is defined with the abbreviation ACAA (art. 57) (Ukraine-European ..., 2014).

On the other hand, the Association Agreement convincingly demonstrates all the efforts of Ukraine in the processes of adaptations to EU acquis: the references to European Union acquis are made twenty times in the text of the Agreement itself, exclusive of annexes. In particular, the Preamble of the Agreement emphasizes that Parties are "COMMITTED to enhancing energy security, ... appropriate infrastructure, market integration and regulatory approximation towards key elements of the EU acquis" and "COMMITTED to gradually approximating Ukraine's legislation with that of the Union along the lines set out in the Agreement" (Ukraine-European ..., 2014). Thereinafter, Ukraine undertakes commitments to implement the provisions of EU acquis to its legislation in Articles 56, 58, 144, 124, 133, 138, 148, 151, 153, 256, and 290 (UkraineEuropean ..., 2014). For comparison, the Lisbon Treaty itself contains the reference to acquis only once - in the sense of acquis of European Law (p. 4, Article 10), and another instance - in the sense of development of "Schengen acquis" (p. 3, Articles 69 F). The references to "Schengen acquis" can also be found in Protocol on Transitional 


\section{Management Theory and Studies for Rural Business and Infrastructure Development \\ eISSN 2345-0355. 2019. Vol. 41. No. 2: 153-167}

Article DOI: https://doi.org/10.15544/mts.2019.14

Provisions (p. 5, art. 10) (Treaty of Lisbon ..., 2007).

It seems as if documenting of aspirations of Ukraine to comply with EU acquis in the Association Agreement is marked by undue detailization and superficial formality focused on ad hoc aim - to maintain specific form and overall presentability of the Agreement and of the processes related to concluding thereof, without taking care of unobvious and deeper levels of meaningfulness and long-term consequences. These, inherent for present day Ukraine, attributes of activity of the authorized persons used to have their analogies at the times of the USSR, and even in the times of the Russian Empire, have been embodied in such social phenomenon as making "window dressing".

\section{Conclusion}

Eurointegration aspirations of Ukraine, which resulted today in signing the Association Agreement with the European Union, are subject to natural fluctuations in the public mood. These fluctuations have historically predetermined the psychological causes that influence on the nature of the contemporary interpersonal communications and public activity, shaping social environment having such features as lack of solidarity, "mutual understanding" of neither each other nor of the common problems of society by certain social strata, and, - as a consequence, there is inefficient activity of the official representatives of Ukraine in external relations, manifesting in negotiations and in signing of treaties, and in practice of their construction and implementation. The motives of the official representatives of the Ukrainian people are poorly correlated with the motivation of Ukrainian people themselves, and this, in its turn, predetermines the low level of relevance of their activity for Ukraine.

In an effort to learn EU acquis, Ukrainians should understand it both in narrow and broad meanings. In a narrow sense, it is a body of the principles and norms including: founding agreements; about 14 thous. of secondary legislative acts, and 9 thous. of the decisions of European Court of Justice. In a broadest sense, "acquis communautaire" is a common groundwork of the Western legal traditions covering Athenian democracy, Roman law, law of self-governed cities and professional corporation of medieval times, the principle of the supremacy of law and the principles of constitutionalism, idea of public society and "human domain" of OSCE, as well as the philosophy of justice, Kant's categorical imperatives under which a person may not be an instrument but only a purpose, and other achievements of XX century in philosophy, sociology, and human science, which, behind iron curtain, remained and still remain unlearned by the prevailing majority of the population of the post-soviet societies, without understanding of which, at least in general terms, the reforms taking place in Ukraine will not be a success. Therefore, a key to success of reforms in Ukraine is to exclude caste privileges and build a civil society, taking into account the experience of the Western legal tradition.

Implementing its European choice, Ukraine should focus not on superficial indicators of well-being that do not have a real basis, but also to master the philosophical- 
legal context of the acquis of European law in its broadest interpretation.

\section{References}

Herodotus (2009). History. Herodotus. History. - Moscow: ACT MOSCOW. 672 p.

Smolii, V.A. (2003). Holodomor of 1932-1933 in the USSR, in: Smolii, V.A. (Eds.) The Encyclopeadia of History of Ukriane. - Kyiv: Nauk. Dumka. 528 p.

World Trade. Mozok.Click. (2017). Textbook. - https://mozok.click/234-svtova-torgvlya.html [2019 04 17].

Ukraine-European Union Association Agreement as of 21 March / 27 June 2014 (2014). https://zakon.rada.gov.ua/laws/show/1678-18\#n2 [2019 04 17].

Partnership and Cooperation Agreement between Ukraine and European Union and Member States: International Document, 14 June 1994 (1994). (invalid, September 1, 2017). -https://zakon2.rada.gov.ua/laws/show/998_012 [2019 04 17].

Proposed Eu. Ukraine Action Plan: Action plan-Programme. EC. (2005). - https://library.euneighbours.eu//content/eu-ukraine-action-plan-0 [2019 04 17].

EU-Ukraine Summit (2008). Council of the European Union. Joint Declarations. Paris, Brussels, 9 September 2008. 12812/08 (Presse 247). - http://www.consilium.europa.eu/ueDocs/cms_Data/docs/pressData/en/er/102633.pdf [2019 04 17].

Treaty on the Functioning of the European Union 2007 (Lisbon version of Treaty of Rome of 1957). - https://eur-lex.europa.eu/legal-content/EN/TXT/?uri=celex\%3A12012E\%2FTXT [2019 04 17].

European Parliament recommendation of 12 July 2007 to the Council on a negotiation mandate for a new enhanced agreement between the European Community and its Member States of the one part and Ukraine of the other part (2007). European Parliament. Strasbourg. - http://www.europarl.europa.eu/sides/getDoc.do?type=TA\&reference=P6-TA-2007-0355\&language=EN $\left[\begin{array}{ll}2019 & 04\end{array}\right.$ 17].

Neboha, M. (2018). Offshore Schemes in Agriculture of Ukraine: Benefits of Exporters and Budget // Losses Commons, 26 March 2018. - https://commons.com.ua/uk/ofshorizaciyaukrayinskoyi-ekonomiki/ [2019 04 17].

Carreau, D., Juillard, P. (2001). International Economic Law, in: Translated from France by V.P. Serebriannikova, V.M. Shumilova. - Moscow: International relations. 608 p.

Negotiations of Doha Development Round of WTO: The Issues on Agriculture. (2015) // The Institute of Economic Research and Political Advice, 5, 33. https://knteu.kiev.ua/file/MTc=/317cab182d75bac222b909a7a58fc357.pdf [2019 04 17].

Baltzer, K. T., Jensen, H. G., \& Lind, K. M. H. (2008). Trade liberalisation in the Doha round - a global and Danish perspective // Nationalфkonomisk tidsskrift, 146(3), 263-300. - https://curis.ku.dk/ws/files/134785892/FOI_WP_2009_1.pdf [2019 04 17].

Agreement on Agriculture. (1994). Verkhovna Rada of Ukraine. Adoption on April 15, 1994. - https://zakon.rada.gov.ua/laws/show/981_005 [2019 04 17].

Agreement on the Application of Sanitary and Phytosanitary Measures. (1994). Verkhovna Rada of Ukraine. Signing on April 15, 1994. - https://zakon.rada.gov.ua/laws/show/981_006 [2019 04 17].

The General Agreement on Tariffs and Trade (GATT 1947). Verkhovna Rada of Ukraine. Revision on April 15, 1994. - https://zakon.rada.gov.ua/laws/show/995_264?lang=en [2019 04 17].

Agreement on Safeguard Measures (1994). Verkhovna Rada of Ukraine. Adoption on January 15, 1994. - https://zakon.rada.gov.ua/laws/show/981_016?lang=en [2019 04 17].

Agreement on Subsidies and Compensation Measures. (1994). Verkhovna Rada of Ukraine. Signing on April 15, 1994. - https://zakon.rada.gov.ua/laws/show/981_015?lang=en [2019 04 17].

European Integration Portal (2017). List of Additives. Ukraine-European Union Association Agreement. - https://eu-ua.org/tekst-uhody-pro-asotsiatsiiu/dodatky [2019 04 17]. 
Treaty of Lisbon amending the Treaty on European Union and the Treaty establishing the European Community. (2007). 13 December 2007. Lisbon // Official Journal of the European Union, C 306/01, 1-229. - https://eur-lex.europa.eu/legal-content/EN/TXT/?uri=uriserv:OJ.C_.2007.306.01.0001.01.ENG [2019 04 17].

Defining EU acquis (2016). Glossary. European Commission. - https://ec.europa.eu/neighbourhood-enlargement/policy/glossary/terms/acquis_en [2019 04 17].

\title{
IŠŠŪKIAI IR GALIMYBĖS UKRAINOS ŽEMĖS ŪKIO RINKOJE PAGAL ASOCIACIJOS SUSITARIMĄ SU EUROPOS SĄJUNGA
}

\author{
Olexandr Radzivill ${ }^{1}$, Tetiana Minka², Yurii Sereda ${ }^{3}$, Oksana Strelchenko ${ }^{4}$, ${ }^{*}$ Yuriy Pyvovar $^{5}$ \\ ${ }^{1,5}$ Doc. dr. Nacionalinis aviacijos universitetas, Kijevas, Ukraina. \\ ${ }^{2}$ Doc. dr. Mokesčiu ir finansu universitetas, Kijevas, Ukraina \\ ${ }^{3}$ Dr. Kijevo nacionalinis ekonomikos universitetas, Ukraina \\ ${ }^{4}$ Doc. dr. Nacionaline Vidaus reikalu akademija, Kijevas, Ukraina
}

Pateikta 201904 26; priimta 20190630

Ukrainos ir ES asociacijos susitarimas, viena vertus, atveria geras perspektyvas didinti Ukrainos žemės ūkio gamintojų konkurencingumą, kita vertus, tai sukelia daug sunkumų, susijusių su bendra Ukrainos visuomenès padètimi.

Šio darbo tikslas - nustatyti Ukrainos žemès ūkio rinkos perspektyvas ir iššūkius (riziką) ịgyvendinant Ukrainos ir ES asociacijos susitarimą. Tyrimo metodai: istorinè-sociologinè, sisteminèstruktūrinè, lyginamoji-teisinè, formali-loginè analizè ir hermeneutiniai tyrimai padèjo ištirti tarptautines visuotines ir regionines sutartis, siekiant suprasti tarptautinių standartų, susijusių su tarptautine prekyba ir jos procesais, turini, liberalizavimą ir jų taikymo ypatumus žemès ūkio sektoriuje taikant Bendraji prekybos tarifą (47) ir globojant Pasaulio prekybos organizacijai.

Tyrimo rezultatai atskleidè eurointegracijos nuotaikų svyravimus Ukrainoje. Irodyta, kad Ukrainos ir ES bendradarbiavimo perspektyvos ir jų iggyvendinimo būdai Ukrainos žemès ūkio rinkoje turètų būti interpretuojami atsižvelgiant $i$ istorines aplinkybes. Ukrainos reformų sèkmès raktas - pašalinti kastų privilegijas ir kurti pilietinę visuomenę, atsižvelgiant į Vakarų teisinès tradicijos patirtį.

Raktiniai žodžiai: tarptautinè žemès ūkio prekyba, Asociacijos susitarimas, Ukrainos visuomenè, Ac-quis communautaire, pilietinè visuomenè, žemès ūkis, perspektyvos ir iššūkiai.

JEL kodai: K33, Q13. 